Original Article

\title{
PHYTOCHEMICAL SCREENING AND BIOLOGICAL EVALUATION OF DYPSIS LEPTOCHEILOS LEAVES EXTRACT AND MOLECULAR DOCKING STUDY OF THE ISOLATED COMPOUNDS
}

\author{
HAITHAM ALI IBRAHIM1* ${ }^{*}$, FATEHIA SAYED ELSHARAWY1, MAHMMOUD ELHASSAB ${ }^{2}$, SAMAH SHABANA ${ }^{3}$, EMAN \\ GABER HAGGAG ${ }^{1}$
}

${ }^{1}$ Department of Pharmacognosy, Faculty of Pharmacy, Helwan University, Ein Helwan, 11795, Cairo, Egypt, ${ }^{2}$ Department of Pharmaceutical chemistry, School of Pharmacy, Badr University, Badr City, 31669, Cairo, Egypt, ${ }^{3}$ Department of Pharmacognosy, Faculty of Pharmaceutical Sciences and Drug Manufacturing, Misr University for Science and Technology. 6 ${ }^{\text {th }}$ of October, 12566, Cairo, Egypt

Email: haithamali081@gmail.com

Received: 20 Aug 2020, Revised and Accepted: 28 Sep 2020

\begin{abstract}
Objective: phytochemical investigation of the ethyl acetate fraction (EAF) of $80 \%$ aqueous methanol extract (AME) of Dypsis leptocheilos leaves, in addition to evaluation of the antioxidant, cytotoxic and antimicrobial activities of the AME and EAF. Docking was used to predict and understand cytotoxicity of the isolated compounds.

Methods: The ethyl acetate fraction (EAF) of Dypsis leptocheilos leaves was subjected to different chromatographic separation techniques. Structures of the isolated compounds were established by different spectroscopic techniques $\left({ }^{1} \mathrm{H} /{ }^{13} \mathrm{C}\right.$ NMR). Antioxidant activity was evaluated by DPPH assay, while cytotoxicity was evaluated by MTT cell viability assay. Antimicrobial activity was evaluated by agar diffusion method. The docking study was conducted using Auto Dock Vina; the estrogen receptor (PDB 5t92) was used as a receptor for the docking.

Results: Chromatographic separation techniques were led to the isolation of five phenolic compounds; these compounds were identified to be apigenin 8-C- $\beta$-D-glucopyranoside (Vitexin) (1), apigenin 6-C- $\beta$-D-glucopyranoside (Isovitexin) (2), luteolin 7-O- $\beta$-D-glucopyranoside (3), luteolin 8C- $\beta$-D-glucopyranoside (Orientin) (4), luteolin 6-C- $\beta$-D-glucopyranoside (Isoorientin) (5). They were isolated and identified for the first time from this plant species. The AME and EAF showed moderate activity against Gram positive and Gram negatvie bacteria, while both of them showed similar and powerful antioxidant activity with $\mathrm{SC}_{50}=12.8 \pm 0.56 \mu \mathrm{g} / \mathrm{ml}$ and $\mathrm{SC}_{50}=17 \pm 0.77 \mu \mathrm{g} / \mathrm{ml}$ respectively, compared to ascorbic (reference drug) $\mathrm{SC}_{50}=14.2 \pm 0.35 \mu \mathrm{g} / \mathrm{ml}$. The EAF showed higher cytotoxic activity on the MCF-7 cells (human breast cancer cell line), with IC $50=12.3 \pm 1.82 \mu \mathrm{g} / \mathrm{ml}$, compared to Vinblastine Sulfate (reference drug). All isolated compounds showed good binding affinity to the estrogen receptors existed in the MCF-7 cell.
\end{abstract}

Conclusion: Five phenolic compounds were isolated for the first time from the EAF of Dypsis leptocheilos leaves. The AME and EAF extracts showed variable antioxidant, antimicrobial and cytotoxic activities.

Keywords: Antimicrobial, Antioxidant, Cytotoxicity, Docking, Dypsis leptocheilos, Polyphenolic

(C) 2020 The Authors. Published by Innovare Academic Sciences Pvt Ltd. This is an open access article under the CC BY license (http://creativecommons.org/licenses/by/4.0/) DOI: http://dx.doi.org/10.22159/ijpps.2020v12i11.39481. Journal homepage: https://innovareacademics.in/journals/index.php/ijpps.

\section{INTRODUCTION}

Medicinal plants are the richest bio-resource of drugs related to the traditional medical system, modern medicines, nutraceuticals, food supplements, folk medicines, pharmaceutical intermediates, and chemical entities for synthetic drugs [1]. The medicinal plants are beneficial for curing human diseases because of the presence of phytochemical constituents. Several important medicinal components are derived from plants like alkaloids, flavonoids tannins, terpenoids, steroids etc [2].

Dypsis is one of the largest single genera in the palm family, with over 170 species ranging from tiny understory plants to massive emergent canopy palms and just about every size in between. Dypsis are an extraordinary phenomenon of evolutionary diversity; this genus is composed of numerous former separate palm genera, including Vonitra, Chrysalidocarpus, Phloga, Neophloga, Phogella, Trichodypsis, Haplodypsis, Adelodypsis, Antogilia, and Neodypsis. Dypsis were catalogued and described in great detail in "The Palms of Madagascar" a seminal work by Dr. John Dransfield and HenkBeentje, first published in 1995 by Kew Botanical Gardens [3] By reviewing the current literature, it was found that no reports dealt with the phytochemical study of D. leptocheilos and this encouraged our team to work for isolation and identification of its Phyto-constituents in addition to evaluation of its therapeutic activities.

On the basis of the fact, that said the development of antibiotic resistance in microorganisms is a global challenge for the clinicians, pharmacist, and research scientists leading to the development of new medicinal formulations that are effective and easily consumable [1] we decided to study antimicrobial activities of D. leptocheilos. As Anti-oxidants play an important role in protecting and safeguarding health problem especially in the disease such as cancer [4] that encouraged our team to measure antioxidant activity of $D$. leptocheilos. Molecular docking of isolated compounds was carried out as it is a method which predicts the preferred orientation of one molecule to a second when bound to each other to form a stable complex [5]. Molecular docking research focuses on computationally simulating the molecular recognition process. It aims to achieve an optimized confirmation for both the protein and ligand and relative orientation between protein and ligand such that the free energy of the overall system is minimized [6].

In this study, the isolation of five phenolic compounds from $D$. leptocheilos leaves extract was reported and their molecular docking study was performed, in addition to the evaluation of the antioxidant, cytotoxic and antimicrobial activities of the AME and EAF extracts.

\section{MATERIALS AND METHODS}

\section{Plant material}

The leaves of Dypsis leptocheilos (Arecaceae) were collected from AlAbed garden, Alexandria-Egypt, desert road in August 2017. The plant material was identified by Dr. Terase Labib, Department of Flora and Taxonomy, Al-Orman Botanical Garden, Giza, Egypt. A 
voucher specimen No.01Dle/2017 was kept in the herbarium in the Department of Pharmacognosy, Faculty of Pharmacy, Helwan University, Egypt

\section{Materials for biological studies}

Mammalian cell lines: MCF-7 cells (human breast cancer cell line) HepG-2 (human hepatocellular carcinoma) and HeLa cells (human cervical cancer cell line), were obtained from the American Type Culture Collection (ATCC, Rockville, MD). Fungi: Aspergillus fumigatus (RCMB 002008) and Candida albicans (RCMB 005003 (1) ATCC 10231), Gram-positive bacteria: Staphylococcus aureus (RCMB010010), Bacillus subtilis (RCMB 015 (1) NRRL B-543), Gramnegative bacteria: Salmonella typhimurium (RCMB 006 (1) ATCC 14028), Escherichia coli (RCMB 010052) were supplied from the Regional Center for Mycology and Biotechnology (RCMB), Al-Azhar University, Cairo, Egypt.

\section{Instruments and chemicals for biological studies}

All cell lines were cultured in DMEM media supplemented with 10\% $(\mathrm{v} / \mathrm{v})$ foetal bovine serum, $2 \mathrm{mmol}$ glutamine and $50 \mu \mathrm{g} / \mathrm{m}$ penicillin/streptomycin solution (all from Invitrogen, Paisley, UK). Dimethyl sulfoxide (DMSO), MTT and trypan blue dyes were purchased from (Sigma-Aldrich) (St. Louis, Mo., USA). Chemicals for evaluating the antimicrobial activity; ascorbic acid, Ketoconazole, Gentamycin and Vinblastine Sulfate were supplied by RCMB: Regional Center for Mycology and Biotechnology, Cairo, Egypt Chemicals used for evaluating the antioxidant activity, DPPH $(2,2$ Diphenyl-1-picrylhydrazyl) and Ascorbic acid were purchased from Sigma-Aldrich Co., UK. Authentic reference flavonoid compounds were supplied by Pharmacognosy department, Faculty of Pharmacy, Helwan University. Authentic sugars were purchased from SigmaAldrich Co., UK. A microplate reader (SunRise, TECAN, Inc, USA), the 96-well plate used for cytotoxicity evaluation using cell viability assay. UV-visible spectrophotometer (Milton Roy, Spectronic 1201), used for measuring the absorbance in the antioxidant assay.

\section{Instruments and materials for chromatographic techniques}

The NMR spectra were recorded using Bruker a $400 \mathrm{MHz}$ for ${ }^{1} \mathrm{H}$ NMR and $100.40 \mathrm{MHz}$ for ${ }^{13} \mathrm{C}$ NMR. The spectra were run in DMSO, and chemical shifts were given as $\delta \mathrm{ppm}$ relative to tetramethylsilane (TMS) as an internal standard. Negative ESI-MS were run on LCQ deca MS and LTQ-FT-MS spectrometers for MS analysis (Thermo Electron, Finnigan, Germany). For column chromatography, silica gel G60 for column chromatography (70-230 mesh, Merk), silica gel G60 for thin layer chromatography (E. Merk, Germany), silica gel GF254 pre-coated TLC plates (E. Merk, Germany), sheets of Whatman filter paper $(1 \mathrm{~mm})$ for paper Chromatography (WhatmanItd, Maid stone, Kent, England), micro crystalline cellulose (E. Merk-Darmstadt, Germany) and polyamide $6 \mathrm{~S}$ (Riedel-De-Haen AG, SeelzeHaen AG, SeelzeHanver, Germany). Solvent systems for paper chromatography: $\mathrm{S}_{1}\left(n-\mathrm{BuOH}-\mathrm{HOAc}-\mathrm{H}_{2} \mathrm{O}\right.$ 4: $1: 5$, top layer), $S_{2}(15 \%$ aqueous HOAc) were used [7].

\section{Extraction and isolation}

Air-dried leaves of D. leptocheilos $(1 \mathrm{~kg})$ were coarsely ground and extracted exhaustively with $80 \%$ methanol $/ \mathrm{H}_{2} \mathrm{O}\left(5 \mathrm{~L} \mathrm{x} 4,60^{\circ} \mathrm{C}, 4 \mathrm{~h}\right)$ Then, the total extract was evaporated to dryness under reduced pressure to yield $115 \mathrm{~g}$ of the dark brown residue. This residue was reconstituted with $300 \mathrm{ml} \mathrm{H}_{2} \mathrm{O}$ then fractionated with $3 \times 300 \mathrm{ml}$ of petroleum ether and ethyl acetate by liquid-liquid phase separation yielding four fractions weighing ( $15 \mathrm{~g}$ petroleum ether fraction, $17 \mathrm{~g}$ ethyl acetate fraction and $65 \mathrm{~g}$ aqueous fraction). 2D-PC of the fractions revealed the presence of a pronounced number of flavonoid spots in the ethyl acetate fraction, which were detected under UV-light and spray reagents. The EAF (10 g) was fractionated on silica gel column $(5 \times 90 \mathrm{~cm})$, the column was eluted using 25:75 petroleum ether $/ \mathrm{CH}_{2} \mathrm{Cl}_{2}$ mixtures with increasing polarity till $100 \%$ $\mathrm{CH}_{2} \mathrm{Cl}_{2}$ then increasing polarity using methanol up to $25: 75$ $\left(\mathrm{MeOH} / \mathrm{CH}_{2} \mathrm{Cl}_{2}\right)$, yielding 46 individual fractions, collected into 6 fractions (I-VI). Fraction I was found to be polyphenolic free. Fraction II ( $450 \mathrm{mg}$ ) was rechromatographed on polyamide column $(2.5 \times 50 \mathrm{~cm})$, the column was eluted using water then $\mathrm{H}_{2} \mathrm{O} / \mathrm{MeOH}$ mixtures $(0-40 \% \mathrm{MeOH})$ to yield 6 subfractions (i-vi), the promising subfraction was subfraction iii, (89 $\mathrm{mg}$ ), showed one dark purple spot which was further purified on cellulose column using $\mathrm{H}_{2} \mathrm{O}$, to afford pure compound 1 (14 mg). Fraction III (650 mg) was fractionated on polyamide column $(3 \times 65 \mathrm{~cm})$, the column was eluted using water then $\mathrm{H}_{2} \mathrm{O} / \mathrm{MeOH}$ mixtures with decreasing polarity to yield 5 subfractions (i-v), the promising fractions were subfractions iii and $\mathrm{v}$, which were further individually purified on cellulose column using $\mathrm{H}_{2} \mathrm{O}$, to afford pure compound 2 (15 mg), compound $3(20 \mathrm{mg})$. Fraction IV (320 mg) was fractionated on a cellulose column using $\mathrm{H}_{2} \mathrm{O}-\mathrm{MeOH}(10-90 \%)$ mixtures, giving two subfractions, $\mathrm{i}$ and ii, which were further individually purified on sephadex LH-20 columns, using EtOH, to afford pure samples of 4 (12 $\mathrm{mg})$ and 5 (10 mg), respectively.

\section{Antioxidant activity (DPPH radical scavenging activity)}

Antioxidant activity of the AME and EAF was determined at the Regional Center for Mycology and Biotechnology (RCMB) at Al-Azhar University by the DPPH free radical scavenging assay in triplicate and mean values were considered [8]. Freshly prepared $(0.004 \%$ $\mathrm{w} / \mathrm{v}$ ) methanol solution of 2, 2-diphenyl-1-picrylhydrazyl (DPPH) radical was prepared and stored at $10^{\circ} \mathrm{C}$ in dark. A methanol solution of the tested extracts were prepared with sample concentrations $(0$, $10,20,40,80,160,320,640,1280 \mu \mathrm{g} / \mathrm{ml})$. A $40 \mu \mathrm{l}$ aliquot of the methanol solution was added to $3 \mathrm{ml}$ of DPPH solution. Absorbance measurements were recorded immediately with a UV-visible spectrophotometer. The decrease in absorbance at $515 \mathrm{~nm}$ was determined continuously, with data being recorded at $1 \mathrm{~min}$ intervals until the absorbance stabilized (16 min). The absorbance of the DPPH radical without antioxidant (control) and the reference compound ascorbic acid were also measured. All the determinations were performed in three replicates and averaged. The percentage of DPPH radical scavenging was calculated according to the formula: (scavenging activity) $=[\{(A C-A T) / A C\} \times 100](1)$. Where $A C=$ Absorbance of the control at $\mathrm{t}=0 \mathrm{~min}$ and $A \mathrm{~T}=$ absorbance of the sample+DPPH at $\mathrm{t}=16 \mathrm{~min}^{3}$.

\section{Antimicrobial activity}

The AME and EAF of D. leptocheilos leaves were assayed for antimicrobial activity using the susceptibility tests. Screening tests regarding the inhibition zone were carried out by the well diffusion method [9]. The inoculum suspension was prepared from colonies grown overnight on an agar plate and inoculated into MuellerHinton broth (fungi using malt broth). A sterile swab was immersed in the suspension and used to inoculate Mueller-Hinton agar plates (fungi using malt agar plates). The extracts were dissolved in dimethyl sulfoxide (DMSO) with different concentrations (10, 5, 2.5 $\mathrm{mg} / \mathrm{ml}$ ). The inhibition zone was measured around each well after $24 \mathrm{~h}$ at $37^{\circ} \mathrm{C}$. Controls using DMSO were adequately done.

\section{Evaluation of cytotoxicity}

The cytotoxic activity of the AME and EAF of D. leptocheilos leaves were evaluated against (HepG2), (MCF-7) and HeLa cell lines using the MTT cell viability assay.

\section{Cell line propagation}

The cells were grown on RPMI-1640 medium supplemented with $10 \%$ inactivated fetal calf serum and $50 \mu \mathrm{g} / \mathrm{ml}$ gentamycin tampicillin. The cells were maintained at $37{ }^{\circ} \mathrm{C}$ in a humidified atmosphere with $5 \% \mathrm{CO}_{2}$ and were subcultured two to three times a week.

\section{Cytotoxicity evaluation using viability assay}

For cytotoxicity assays, the cancer cell lines were suspended in media at concentration $5 \times 10^{4}$ cell/well in Corning® 96-well tissue culture plates, and then incubated for $24 \mathrm{~h}$. The tested AME and EAF were then added into 96-well plates (three replicates) to achieve twelve concentrations for each extract. Six vehicle controls with media or 0.5 $\%$ DMSO were run for each 96-well plate as a control. After incubating for $24 \mathrm{~h}$, the numbers of viable cells were determined by the MTT test. Briefly, the media was removed from the 96-well plates and replaced with $100 \mu \mathrm{l}$ of fresh culture RPMI 1640 medium without phenol red then $10 \mu \mathrm{l}$ of the $12 \mathrm{mmol}$ MTT stock solution ( $5 \mathrm{mg}$ of MTT in $1 \mathrm{ml}$ of PBS) to each well, including the untreated controls. The 96-well plates 
were then incubated at $37{ }^{\circ} \mathrm{C}$ and $5 \% \mathrm{CO}_{2}$ for $4 \mathrm{~h}$. An $85 \mu \mathrm{l}$ aliquot of the media was removed from the wells, and $50 \mu \mathrm{l}$ of DMSO was added to each well and mixed thoroughly with the pipette and incubated at $37^{\circ} \mathrm{C}$ for $10 \mathrm{~min}$. Then, the optical density was measured at $590 \mathrm{~nm}$ with the microplate reader (SunRise, TECAN, Inc, USA) to determine the number of viable cells and the percentage of viability was calculated as [(ODt/ODc)] $\times 100 \%$ where ODt is the mean optical density of wells treated with the tested sample and ODc is the mean optical density of untreated cells. The relation between surviving cells and drug plotted to get the survival curve of each cell line. The $50 \%$ inhibitory concentration $\left(\mathrm{IC}_{50}\right)$, required to cause toxic effects in $50 \%$ of intact cells, was estimated from graphic plots of the dose-response curve for each concentration. Using Graph pad Prism software (San Diego, CA. USA) $[10,11]$

\section{Statistical analysis of data}

All the experimental results were expressed as mean \pm SD. Analysis of variance was performed by ANOVA procedures. Correlation coefficient $\left(\mathrm{R}^{2}\right)$ was used to determine two variables. SPSS software was used for statistical calculations. The results with $p<0.05$ were regarded to be statistically significant.

\section{Docking studies}

The docking study was conducted using Auto Dock Vina, M. G. L tools 1.5.7 and Discovery Studio 4.5 as a visualizer. The estrogen receptor (PDB 5t92) was used as a receptor for the docking of the five compounds. To ensure a valid docking and to evaluate the effect of the water molecules, the co-crystalized ligand in the estrogen receptor was docked to its corresponding protein (in absence and in the presence of water) and the RMSD values between the cocrystalized ligand and the docked pose were calculated. The active site of the estrogen receptor has been determined from the binding of co-crystalized ligand. The energy minimized estrogen receptor the co-crystalized ligand and the three isolated compounds were finally prepared in the right format using MGL tools 1.5.7 for conducting docking study by Auto Dock Vina that requires both the receptor and the ligands in pdbqt format [12]. Grid was generated for the receptor using MGL tools 1.5.7. Auto Dock Vina achieves approximately two orders of magnitude speed-up compared to the molecular docking software Auto Dock 4, while also significantly improving the accuracy of the binding mode predictions. Further speed-up is achieved from parallelism, using multithreading on multi-core machines. Auto Dock Vina uses Auto Dock score that calculates free binding energies and iterated local search global optimization algorithm [13-15]. The result of docking was visually inspected by discovery studio 4.5 visualizer. The evaluation of candidates was based on binding affinity and interaction with the receptor.

\section{RESULTS AND DISCUSSION}

\section{Characterization and identification of isolated compounds}

Chromatographic separation of EAF of D. leptocheilos leaves resulted in five compounds. Structures of the isolated compounds (fig. 1) were identified by different spectral techniques including ${ }^{1} \mathrm{H}$ NMR, ${ }^{13} \mathrm{C}$ NMR, ESI-MS and CoPC against standard authentic after complete acid hydrolysis.

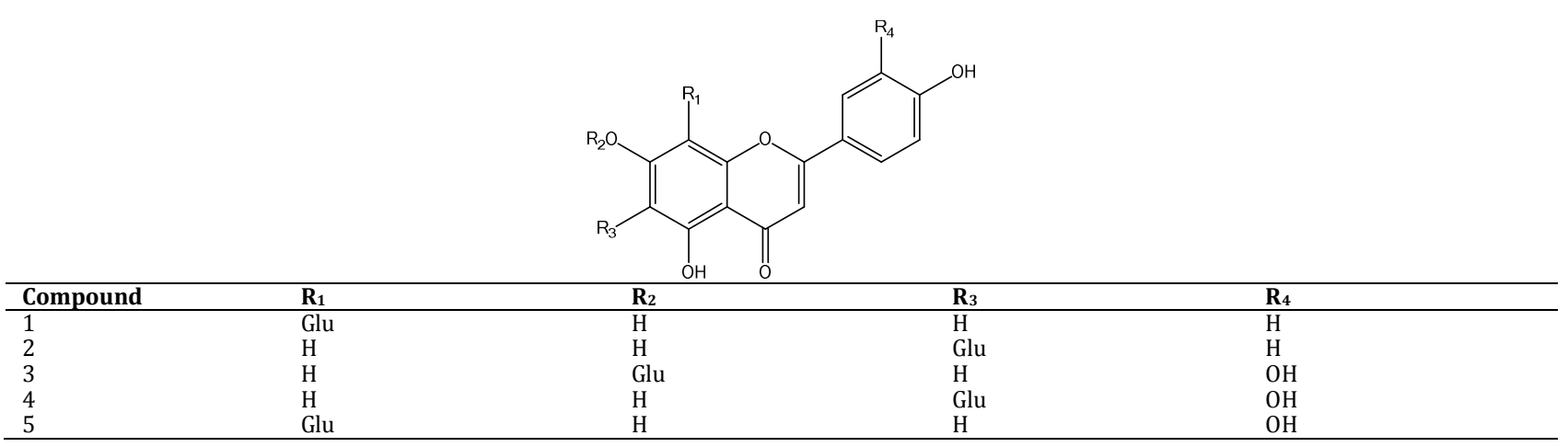

Fig. 1: Chemical structures of the isolated compounds from $D$. leptocheilos leaves

Table 1: ${ }^{1} \mathrm{H}$ NMR (400 MHz, DMSO-d6), ${ }^{13} \mathrm{C}$ NMR (100.40 MHz, DMSO-d6) of compound 1, 2, 4 and 5

\begin{tabular}{|c|c|c|c|c|c|c|c|c|c|}
\hline \multirow[t]{2}{*}{ C-No } & \multicolumn{2}{|c|}{ Compound 1} & \multicolumn{2}{|c|}{ Compound 2} & \multirow{2}{*}{$\begin{array}{l}\text { C- } \\
\text { No }\end{array}$} & \multicolumn{2}{|c|}{ Compound 4} & \multicolumn{2}{|c|}{ Compound 5} \\
\hline & $\delta \mathrm{C}$ & 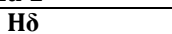 & $\delta \mathrm{C}$ & Ho & & $\delta \mathrm{C}$ & Ho & $\delta \mathrm{C}$ & Ho \\
\hline 2 & 164.31 & & 163.23 & & 2 & 164.17 & & 164.57 & \\
\hline $\begin{array}{l}3 \\
4\end{array}$ & $\begin{array}{l}102.85 \\
182.48\end{array}$ & $6.72, \mathrm{~s}$ & $\begin{array}{l}102.96 \\
181.81\end{array}$ & $6.69, \mathrm{~s}$ & $\begin{array}{l}3 \\
4\end{array}$ & $\begin{array}{l}103.11 \\
182.40\end{array}$ & $6.68, \mathrm{~s}$ & $\begin{array}{l}102.75 \\
182.54\end{array}$ & $6.65, \mathrm{~s}$ \\
\hline 5 & 161.72 & & 161.76 & & 5 & 163.73 & & 160.99 & \\
\hline 6 & 98.75 & $6.19, \mathrm{~s}$ & 109.59 & & 6 & 109.19 & & 98.48 & $6.28, \mathrm{~s}$ \\
\hline 7 & 161.68 & & 161.13 & & 7 & 160.97 & & 162.98 & \\
\hline 8 & 106.08 & & 94.64 & $6.39, \mathrm{~s}$ & 8 & 93.91 & $6.49, \mathrm{~s}$ & 104.91 & \\
\hline 9 & 156.46 & & 156.97 & & 9 & 156.68 & & 156.33 & \\
\hline 10 & 104.32 & & 102.96 & & 10 & 104.09 & & 104.31 & \\
\hline 1 & 122.02 & & 121.57 & & $1^{\prime}$ & 121.75 & & 122.33 & \\
\hline $\begin{array}{l}2 / 6 \\
3 / 5\end{array}$ & $\begin{array}{l}128.89 \\
116.29\end{array}$ & $\begin{array}{l}8.00, \mathrm{~d},(8.22) \\
6.90, \mathrm{~d},(8.61)\end{array}$ & $\begin{array}{l}128.73 \\
116.49\end{array}$ & $\begin{array}{l}7.90, \mathrm{~d},(8.51) \\
6.92, \mathrm{~d},(8.58)\end{array}$ & $\begin{array}{l}2^{\prime} \\
3^{\prime}\end{array}$ & $\begin{array}{l}113.91 \\
146.14\end{array}$ & $7.41, \mathrm{~d},(2.4)$ & $\begin{array}{l}114.48 \\
146.51\end{array}$ & $7.49, \mathrm{~d},(2.4)$ \\
\hline 4 & 160.85 & & 159.20 & & $4^{\prime}$ & 150.07 & & 150.04 & \\
\hline $\begin{array}{l}1 " \\
2 " \\
3 " \\
4 " \\
5 " \\
6 "\end{array}$ & $\begin{array}{l}73.89 \\
71.35 \\
79.13 \\
70.65 \\
82.28 \\
61.75\end{array}$ & $\begin{array}{l}4.72, \mathrm{~d},(9.93) \\
3.2-3.7, \mathrm{~m}, \\
\text { remaining of } \\
\text { sugar protons }\end{array}$ & $\begin{array}{l}73.81 \\
71.01 \\
79.54 \\
70.65 \\
81.86 \\
61.82\end{array}$ & $\begin{array}{l}4.59, \mathrm{~d},(9.88) \\
3.2-3.7, \mathrm{~m}, \\
\text { remaining of } \\
\text { sugar protons }\end{array}$ & $\begin{array}{l}5 ' \\
6 ' \\
1^{\prime \prime} \\
2^{\prime \prime} \\
3^{\prime \prime} \\
4^{\prime \prime}\end{array}$ & $\begin{array}{l}116.54 \\
119.23 \\
73.50 \\
71.14 \\
79.18 \\
70.41\end{array}$ & $\begin{array}{l}6.90, \mathrm{~d},(8.25) \\
7.44, \mathrm{dd},(2.4 \text { and } 8.25) \\
4.59, \mathrm{~d},(9.81) \\
4.05, \mathrm{t}-\mathrm{like} \\
3.15-3.89, \mathrm{~m}, \\
\text { remaining of sugar }\end{array}$ & $\begin{array}{l}116.06 \\
119.97 \\
73.48 \\
71.17 \\
79.03 \\
62.10\end{array}$ & $\begin{array}{l}\text { 6.86,d,(8.97) } \\
7.54, \mathrm{dd},(2.4 \text { and } 8.97) \\
4.69, \mathrm{~d},(9.83) \\
4.99, \mathrm{~s} \\
3.15-.3 .89, \mathrm{~m}, \\
\text { remaining of sugar }\end{array}$ \\
\hline
\end{tabular}




$\begin{array}{lllll}5 " & 81.92 & \text { protons } & 82.37 & \text { protons } \\ 6 " & 61.94 & & 56.87 & \end{array}$

Values between parentheses represent the $J$-values in $\mathrm{Hz}$

Compound 1 and 2 were isolated as yellow amorphous powder each chromatographic properties; R $\mathrm{R}_{\mathrm{f}}$-values $\left(0.43 \mathrm{~S}_{1}, 0.49 \mathrm{~S}_{2}\right)$ and $\left(0.57 \mathrm{~S}_{1}\right.$, $0.55 \mathrm{~S}_{2}$ ) respectively, they gave dark purple spot under UV-light, turned to yellowish-green on exposure to $\mathrm{NH}_{3}$ vapors, grayish-yellow fluorescence on exposure to Naturstoff and green color with $\mathrm{FeCl}_{3}$ spray reagents. Based on its chromatographic properties, they were expected to be an apigenin structure [7]. This expectation was supported by ${ }^{1} \mathrm{H}$ NMR spectrum of 1 and 2 (table 1) which showed an $\mathrm{A}_{2} \mathrm{X}_{2}$ spin coupling system of two ortho-doublets, each integrated for two Protons at $\delta$ ppm $8.00\left(2 \mathrm{H}, \mathrm{d}, J=8.22 \mathrm{~Hz} \mathrm{H}-2^{\prime} / 6^{\prime}\right)$ and $6.90(2 \mathrm{H}, \mathrm{d}$ $\left.J=8.61 \mathrm{~Hz} \mathrm{H}-3^{`} / 5^{`}\right)$ for $1,7.90\left(2 \mathrm{H}, \mathrm{d}, J=8.51 \mathrm{~Hz} \mathrm{H}-2{ }^{\prime} / 6^{\prime}\right)$ and 6.92 $\left(2 \mathrm{H}, \mathrm{d}, J=8.58 \mathrm{~Hz} \mathrm{H}-3^{\prime} / 5^{\prime}\right)$ for 2 indicated 4 -hydroxy B-ring. The glycoside moiety in both compounds was identified as $\beta$-C-glucoside from doublets at $\delta 4.72$ and 4.59 with large $J$ values $(\geq 9 \mathrm{~Hz}$ ) for compounds 1 and 2, respectively. Absence of $\mathrm{H}-8$ and $\mathrm{H}-6$ signals from ${ }^{1} \mathrm{H}$ NMR spectrum of 1 and 2 led us to conclude that the $\mathrm{C}$ glycosylation must be on C- 8 in case of 1 and C- 6 in case of 2 . This evidence was confirmed from the downfield shift of C-8 to 106.08 and C-6 to $109.59(\sim+10 \mathrm{ppm})$ in ${ }^{13} \mathrm{C}$ NMR spectra (table 1 ) of compound 1 and 2 respectively; moreover, the $\mathrm{C}$-glycoside moiety in the structures was confirmed as $\beta$-C-glucopyranoside depending on the characteristic up field location of C- $1^{\prime \prime}$ at $\delta 73.89$ ppm for compound 1 and at $\delta 73.81$ ppm for compound 2 and downfield location of both C-5" and C-3" at $\delta$ 82.28 and 79.13 ppm respectively, for compound 1 and at 81.86 and $79.54 \mathrm{ppm}$ for compound 2 with respect to those of $O$-glycosides. The assignment of all other ${ }^{13} \mathrm{C}$ resonances of compounds 1 and 2 was achieved by comparison with the corresponding data of structural related compounds [16-21]. Negative ESI-MS spectra of compounds 1 and 2 exhibited the molecular ion peak at $m / z \quad 431\{\mathrm{M}-\mathrm{H}\}$ corresponding to the Mwt of 432 and molecular formula of $\mathrm{C}_{21} \mathrm{H}_{20} \mathrm{O}_{10}$ to support evidence of apigenin mono-hexoside structure of both compounds. According to the above-discussed data as well as comparison with authentic samples, compound 1 was confirmed as apigenin-8-C- $\beta$-D-glucopyranoside (Vitexin) and compound 2 as apigenin-6-C- $\beta$-D-glucopyranoside (Isovitexin), which was isolated for the first time from $D$. leptocheilos.

Compounds 4 and 5 were obtained as yellow amorphous powder, chromatographic properties, Rf-values for $4\left(0.43 \mathrm{~S}_{1}, 0.39 \mathrm{~S}_{2}\right)$ and $(0.29$ $S_{1}, 0.21 S_{2}$ ) for 5 , they gave dark purple spot under UV-light, turned to yellow on exposure to $\mathrm{NH}_{3}$ vapors, orange fluorescence on exposure to Naturstoff and green color with $\mathrm{FeCl}_{3}$ spray reagents, Compound 4 and 5 were expected to be a luteolin structure [3]. ${ }^{1} \mathrm{H}$ NMR spectra (table 1) showed an $A B X$-spin coupling system of three proton resonances at $\delta 7.44\left(1 \mathrm{H}, \mathrm{d}, J=2.4\right.$ and $\left.8.25 \mathrm{~Hz}, \mathrm{H}-6^{\prime}\right), 7.41\left(1 \mathrm{H}, \mathrm{d}, J=2.4 \mathrm{~Hz}, \mathrm{H}-2^{\prime}\right)$ and ortho-doublet at $\delta 6.90\left(1 \mathrm{H}, \mathrm{d}, J=8.25 \mathrm{~Hz}, \mathrm{H}-5^{\prime}\right)$ for 4 and $\delta 7.54$ $\left(1 \mathrm{H}, \mathrm{d}, J=2.4\right.$ and $\left.8.97 \mathrm{~Hz}, \mathrm{H}-6^{\prime}\right), 7.49\left(1 \mathrm{H}, \mathrm{d}, J=2.4 \mathrm{~Hz}, \mathrm{H}-2^{\prime}\right)$ and ortho-doublet at $\delta 6.86(1 \mathrm{H}, \mathrm{d}, J=8.97 \mathrm{~Hz}, \mathrm{H}-5)$ for 5 , indicating that both 4 and 5 are luteolin derivatives. in the aliphatic region, the doublets at $\delta 4.59$ and 4.69 with large $J$ values $(>9 \mathrm{~Hz}$ ) for the anomeric protons of 4 and 5 respectively, were intrinsic for a $\beta$-Cglycoside moiety in both compounds. Absence of H-6 and H-8 signals from ${ }^{1} \mathrm{H}$ NMR of 4 and 5 , respectively, was confirmative for Cglycosylation at C-6 in case of 4 and C-8 in case of 5 . As further confirmation, ${ }^{13} \mathrm{C}$ NMR spectrum for each compound (table 1) showed well-resolved typical 15 signals of a luteolin aglycone moiety, including the three key signals of C- $3^{\prime}, \mathrm{C}^{\prime} 4^{\prime}$ and C-3 at $\delta$ ppm 146.14, 150.07 and 103.11 for compound 4 and at $\delta$ ppm 146.51, 150.04 and 102.75 for 5 . Additionally, the C-glycoside moiety in both structures was confirmed as $\beta$-glucopyranoside depending on the characteristic up-field location of $\mathrm{C}-1$ " at 73.50 and 73.48 ppm for compound 3 and compound 4 , respectively, and downfield location of both $C-5^{\prime \prime}$ and $C-3^{\prime \prime}$ to $\delta 81.92$ and $79.18 \mathrm{ppm}$ for compound 3 and to $\delta 82.37$ and $79.03 \mathrm{ppm}$ for compound 4, with respect to those of $O$-glycosides [18]. The Cglycosidation at C-6 in 4 and at C-8 in 5 was concluded from the downfield shift of ${ }^{13} \mathrm{C}$-signals of $\mathrm{C}-6$ to 109.19 and of $\mathrm{C}-8$ to $\delta$ 104.91( $\sim 10 \mathrm{ppm})$ for 4 and 5 respectively. The assignment of all other ${ }^{13} \mathrm{C}$ NMR resonances was achieved by comparison with the corresponding data of structural related compounds [22-24]. Negative ESI-MS spectra of 4 and 5 exhibited the molecular ion peak at $m / z 447$ $\{\mathrm{M}-\mathrm{H}\}$-corresponding to the Mwt of 448 and molecular formula of $\mathrm{C}_{21} \mathrm{H}_{20} \mathrm{O}_{11}$. Thus according to the above-discussed data, compound 4 was confirmed as luteolin-6-C- $\beta$-D-glucopyranoside (Isoorientin), while compound 5 was confirmed as luteolin-8-C- $\beta$-D-glucopyranoside (Orientin). However, both compounds were isolated for the first time from $D$. leptocheilos.

Compound 3, Isolated as yellow amorphous powder, ${ }^{1} \mathrm{H}$ NMR: $\delta$ ppm $7.46\left(1 \mathrm{H}, \mathrm{dd}, J=7.94,1.8 \mathrm{~Hz}, \mathrm{H}-6^{\prime}\right), 7.43\left(1 \mathrm{H}, \mathrm{d}, J=1.8 \mathrm{~Hz}, \mathrm{H}-2^{\prime}\right), 6.92$ $\left(1 \mathrm{H}, \mathrm{d}, J=7.94 \mathrm{~Hz}, \mathrm{H}-5^{\prime}\right), 6.80(1 \mathrm{H}, \mathrm{d}, J=1.8 \mathrm{~Hz}, \mathrm{H}-8), 6.75(1 \mathrm{H}, \mathrm{s}, \mathrm{H}-3)$, $6.45(1 \mathrm{H}, \mathrm{d}, J=1.8 \mathrm{~Hz}, \mathrm{H}-6), 5.09\left(1 \mathrm{H}, \mathrm{d}, J=6.83 \mathrm{~Hz}, \mathrm{H}-1{ }^{\prime \prime}\right), 3.73-3.17(5$ $\mathrm{H}, \mathrm{m}, \mathrm{H}-2^{\prime \prime}, 3^{\prime \prime}, 4 ", 5^{\prime \prime}$ and $\left.6^{\prime \prime}\right) .{ }^{13} \mathrm{C}$ NMR (100.40 MHz, DMSO-d6): $\delta$ 182.36 (C-4), 164.95 (C-2), 163.40 (C-7), 161.59 (C-5), 157.41 (C-9),

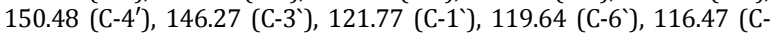
5), 113.28 (C-2'), 105.80 (C-10), 103.58 (C-3), 100.36 (C-1”), 100.00 (C-6), 95.21 (C-8), 77.61 (C-5"), 76.83 (C-3“), 73.57 (C-2"), 70.02 (C4 "), 61.08 (C-6"). Negative ESI-MS spectra of compound 3 exhibited the molecular ion peak at $m / z 447\{\mathrm{M}-\mathrm{H}\}$-corresponding to the Mwt of 448 and a molecular formula of $\mathrm{C}_{21} \mathrm{H}_{20} \mathrm{O}_{11}$. The ${ }^{1} \mathrm{H}$ NMR spectrum showed two meta-coupled doublets $(J=1.9 \mathrm{~Hz})$ at $\delta 6.80$ and 6.45 , each integrating for one proton, and were assigned to $\mathrm{H}-8$ and $\mathrm{H}-6$, respectively of ring $A$ of 5, 7-dihydroxyfavonoids. The presence of $\mathrm{ABX}$ system at $\delta 7.46(\mathrm{dd}, J=7.94,1.8 \mathrm{~Hz}), 7.43(\mathrm{~d}, J=1.8 \mathrm{~Hz})$ and $6.92(\mathrm{~d}, J$ $=7.94 \mathrm{~Hz}$ ), characteristic of 1, 2, 4-trisubstituted phenyl unit. The only singlet at $\delta 6.75$, integrating for one proton, was attributed C-3 to proton of flavonoids. These spectral data revealed the presence of luteolin skeleton. In addition, the ${ }^{1} \mathrm{H}$ NMR spectrum showed a series of signals between $\delta 3.73-3.15$, attributable to the sugar moiety. The coupling constant $U=6.83 \mathrm{~Hz}$ ) of the anomeric proton located at $\delta$ 5.09 and the ${ }^{13} \mathrm{C}$ NMR chemical shifts of the sugar carbons $(\delta 100.36$, $77.61,76.83,73.57,70.02$ and 61.08 ) revealed the presence of $\beta$ - $O$ glucoside unit in luteolin-7-O-glucoside. The ${ }^{13} \mathrm{C}$ NMR data showed the presence of a ketone carbonyl ( $\delta$ 182.36), two olefinic carbons $(\delta$ $164.95 \mathrm{C}-2$ and $103.58 \mathrm{C}-3)$, and four hydroxyl carbons $(\delta 163.40 \mathrm{C}-7$, $161.59 \mathrm{C}-5,150.48 \mathrm{C}-4$ and $\left.146.27 \mathrm{C}-3^{\prime}\right)$. The assignment of all other ${ }^{13} \mathrm{C}$ resonances of 3 was achieved by comparison with the corresponding data of structurally related compounds [25]. According to the above-discussed data as well as comparison with authentic samples, compound 3 was confirmed as luteolin-7-O-glucoside, which was isolated for the first time from $D$. leptocheilos.

Table 2: Antioxidant activity (scavenging activity) of the AME and EAF of D. leptocheilos leaves

\begin{tabular}{|c|c|c|c|c|c|c|}
\hline \multirow{3}{*}{$\begin{array}{l}\text { Sample conc. } \\
(\mu \mathrm{g} / \mathrm{ml})\end{array}$} & \multicolumn{6}{|c|}{ Mean of DPPH scavenging \% } \\
\hline & \multicolumn{2}{|l|}{ AME } & \multicolumn{2}{|l|}{ EAE } & \multicolumn{2}{|c|}{ Ascorbic } \\
\hline & Mean & SD ( \pm ) & Mean & SD ( \pm ) & Mean & SD ( \pm ] \\
\hline 1280 & 90.11 & 1.83 & 89.04 & 1.26 & 93.45 & 1.08 \\
\hline 640 & 86.64 & 0.68 & 87.03 & 0.25 & 88.64 & 0.99 \\
\hline 320 & 84.28 & 0.46 & 85.48 & 0.51 & 80.92 & 1.64 \\
\hline 160 & 81.86 & 0.59 & 83.28 & 1.39 & 75.68 & 1.59 \\
\hline 80 & 80.46 & 0.74 & 81.66 & 1.04 & 66.13 & 4.45 \\
\hline 40 & 76.40 & 1.02 & 78.67 & 3.03 & 53.21 & 1.81 \\
\hline 20 & 74.38 & 4.31 & 58.87 & 4.02 & 20.31 & 3.11 \\
\hline 10 & 40.27 & 1.57 & 29.28 & 1.42 & 11.80 & 2.09 \\
\hline
\end{tabular}

Results are means \pm SD $(\mathrm{n}=3) P<0.05$ 


\section{Antioxidant activity}

Free radicals are known as Reactive Oxygen Species (ROS) are produced by the human body. Plants are potential sources of natural antioxidants that protects the cells against the damaging effects of reactive oxygen species (ROS) [26]. The scavenging ability of DPPH radical is widely used for antioxidant evaluation of natural products besides other several in vitro complementary assays based on inactivation of 02-and NO radicals [27]. DPPH assay was selected to evaluate the antioxidant power of the extracts. The AME and EAF of $D$ leptocheilos showed similar and powerful antioxidant activity with $\mathrm{SC}_{50}=12.8 \pm 0.56 \mu \mathrm{g} / \mathrm{ml}$ and $\mathrm{SC}_{50}=17 \pm 0.77 \mu \mathrm{g} / \mathrm{ml}$ respectively when compared to ascorbic acid $\mathrm{SC}_{50}=14.2 \pm 0.35 \mu \mathrm{g} / \mathrm{ml}$ and (table 2).

\section{Antimicrobial activity}

Results which compiled in table 3, showed that The AME and EAF of D. leptocheilos leaves displayed moderate activity against Grampositive and Gram-negative bacteria; however, both of them possess no anti-fungal activity.

\section{Evaluation of cytotoxicity}

Results of the cytotoxic activity of the AME and EAF of D. lepticheilos leaves against MCF-7, HepG2 and HeLa cell lines are represented in tables $(4,5,6$ and 7$)$

Table 3: Antimicrobial activity of the AME and EAF of $D$. leptocheilos leaves

\begin{tabular}{|c|c|c|c|c|c|c|}
\hline \multirow[t]{2}{*}{ Sample tested microorganisms } & \multicolumn{2}{|l|}{ AME } & \multicolumn{2}{|l|}{ EAF } & \multicolumn{2}{|l|}{ Control } \\
\hline & Mean IZ & SD ( \pm ) & Mean IZ & SD ( \pm ) & Mean IZ & SD ( \pm ) \\
\hline Fungi & & & & & Ketoconazole & \\
\hline Aspergillusfumigatus & NA & NA & NA & NA & 21.01 & 0.02 \\
\hline Candida albicans & NA & NA & NA & NA & 23.03 & 0.04 \\
\hline Gram Positive Bacteria & & & & & Gentamycin & \\
\hline Staphylococcus aureus & 10.00 & 1.00 & 12.00 & 1.00 & 30.01 & 0.01 \\
\hline Bacillus subtilis & 8.50 & 0.50 & 7.50 & 0.50 & 26.02 & 0.03 \\
\hline Gram Negative Bacteria & & & & & Gentamycin & \\
\hline Salmonella typhimurium & NA & NA & 10.50 & 0.50 & 33.02 & 0.03 \\
\hline Escherichia coli & 9.50 & 0.50 & 11.50 & 0.50 & 27.09 & 0.01 \\
\hline
\end{tabular}

*NA: No activity. The sample was tested at concentration $10 \mathrm{mg} / \mathrm{ml} .(\mathrm{n}=3)$

Table 4: Cytotoxic activity (viability \%) of the AME and EAF of $D$. leptocheilos leaves against MCF-7 cell line compared to vinblastine sulfate

\begin{tabular}{|c|c|c|c|c|c|c|}
\hline \multirow{3}{*}{ Sample conc. $(\mu \mathrm{g} / \mathrm{ml})$} & \multicolumn{6}{|c|}{ Mean of viability \% MCF-7 cell line } \\
\hline & \multicolumn{2}{|c|}{ AME } & \multicolumn{2}{|l|}{ EAF } & \multicolumn{2}{|c|}{ Vinblastine } \\
\hline & Mean & SD $( \pm)$ & Mean & SD $( \pm)$ & Mean & $S D( \pm)$ \\
\hline 500 & 4.57 & 0.24 & 3.40 & 0.22 & 4.12 & 0.17 \\
\hline 250 & 6.36 & 0.38 & 6.93 & 0.49 & 7.24 & 0.38 \\
\hline 125 & 12.54 & 0.79 & 12.67 & 0.72 & 13.78 & 0.87 \\
\hline 62.5 & 23.44 & 1.39 & 22.30 & 1.92 & 19.00 & 2.22 \\
\hline 31.25 & 33.15 & 2.64 & 34.11 & 2.87 & 26.40 & 3.01 \\
\hline 15.6 & 44.79 & 2.78 & 44.49 & 2.73 & 37.05 & 1.47 \\
\hline 7.8 & 59.50 & 3.02 & 57.91 & 4.70 & 43.96 & 2.28 \\
\hline 3.9 & 74.41 & 3.52 & 73.93 & 4.54 & 53.96 & 2.06 \\
\hline 2.00 & 100 & ----- & 100 & ----- & 61.38 & 2.52 \\
\hline 1.00 & --- & --- & ---- & --- & 69.21 & 3.73 \\
\hline
\end{tabular}

Results are means \pm SD (n=3) $P<0.05$

Table 5: Cytotoxic activity (viability \%) of the AME and EAF of $D$. leptocheilos leaves against HepG-2 cell line compared to vinblastine sulfate

\begin{tabular}{|c|c|c|c|c|c|c|}
\hline \multirow{3}{*}{ Sample conc. $(\mu \mathrm{g} / \mathrm{ml})$} & \multicolumn{6}{|c|}{ Mean of viability \% HepG-2 cell line } \\
\hline & \multicolumn{2}{|c|}{ AME } & \multicolumn{2}{|l|}{ EAF } & \multicolumn{2}{|c|}{ Vinblastine } \\
\hline & Mean & SD ( \pm ) & Mean & SD ( \pm ) & Mean & SD ( \pm ) \\
\hline 500 & 4.43 & 0.19 & 4.02 & 0.22 & 3.91 & 0.16 \\
\hline 250 & 7.67 & 0.34 & 7.15 & 0.27 & 6.77 & 0.35 \\
\hline 125 & 11.82 & 0.32 & 13.64 & 0.99 & 10.38 & 0.44 \\
\hline 62.5 & 22.38 & 1.95 & 24.52 & 0.93 & 14.89 & 1.68 \\
\hline 31.25 & 33.22 & 1.61 & 38.20 & 1.30 & 24.33 & 2.33 \\
\hline 15.6 & 41.87 & 0.92 & 47.09 & 1.55 & 33.00 & 1.09 \\
\hline 7.8 & 54.86 & 1.62 & 63.97 & 1.89 & 41.94 & 1.24 \\
\hline 3.9 & 69.29 & 1.33 & 79.62 & 3.08 & 47.62 & 1.83 \\
\hline 2.00 & 100 & ----- & 100 & ----- & 56.84 & 2.48 \\
\hline 1.00 & --- & --- & ---- & --- & 65.76 & 1.19 \\
\hline
\end{tabular}

Results are means \pm SD $(\mathrm{n}=3) P<0.05$

Table 6: Cytotoxic activity (viability \%) of the AME and EAF of D. leptocheilos leaves against hela cell line compared to vinblastine sulfate

\begin{tabular}{|c|c|c|c|c|c|c|}
\hline \multirow[t]{3}{*}{ Sample conc. $(\mu \mathrm{g} / \mathrm{ml})$} & \multicolumn{6}{|c|}{ Mean of viability\% HeLa cell line } \\
\hline & \multicolumn{2}{|c|}{ AME } & \multicolumn{2}{|l|}{ EAF } & \multicolumn{2}{|c|}{ Vinblastine } \\
\hline & Mean & SD ( \pm ) & Mean & SD ( \pm ) & Mean & SD ( \pm ) \\
\hline 500 & 6.35 & 0.46 & 5.48 & 0.53 & 5.12 & 0.89 \\
\hline 250 & 11.62 & 0.83 & 10.62 & 0.75 & 9.08 & 1.33 \\
\hline 125 & 23.11 & 1.96 & 19.26 & 1.69 & 15.31 & 1.29 \\
\hline 62.5 & 34.29 & 2.31 & 31.53 & 3.06 & 23.79 & 2.79 \\
\hline 31.25 & 45.13 & 3.38 & 39.24 & 2.35 & 29.96 & 3.16 \\
\hline
\end{tabular}




\begin{tabular}{|c|c|c|c|c|c|c|}
\hline 15.6 & 60.79 & 3.58 & 52.46 & 3.62 & 38.47 & 2.57 \\
\hline 7.8 & 81.28 & 3.41 & 70.00 & 3.75 & 46.42 & 0.70 \\
\hline 3.9 & 89.82 & 4.86 & 85.62 & 3.41 & 57.55 & 3.05 \\
\hline 2.00 & 100 & ------ & 100 & ------ & 66.50 & 2.35 \\
\hline 1.00 & --- & ---- & ---- & ---- & 73.66 & 2.37 \\
\hline
\end{tabular}

Results are means \pm SD $(\mathrm{n}=3) P<0.05$

Table 7: IC 50 values of the standard drug, the AME and EAF of D. leptocheilos leaves

\begin{tabular}{llll}
\hline Sample & MCF-7 & HeLa & HepG2 \\
\hline AME & $\mathrm{IC}_{50}=12.8 \pm 1.04 \mu \mathrm{g} / \mathrm{ml}$ & $\mathrm{IC} 50=26.3 \pm 2.83 \mu \mathrm{g} / \mathrm{ml}$ & $\mathrm{IC} 50=10.7 \pm 0.37 \mu \mathrm{g} / \mathrm{ml}$ \\
EAF & $\mathrm{IC}_{50}=12.3 \pm 1.82 \mu \mathrm{g} / \mathrm{ml}$ & $\mathrm{I} C_{50}=18.5 \pm 3.29 \mu \mathrm{g} / \mathrm{ml}$ & $\mathrm{IC} \mathrm{C}_{50}=14.2 \pm 0.60 \mu \mathrm{g} / \mathrm{ml}$ \\
Vinblastine Sulfate & $\mathrm{IC}_{50}=5.44 \pm 0.57 \mu \mathrm{g} / \mathrm{ml}$ & $\mathrm{IC} 50=6.54 \pm 0.39 \mu \mathrm{g} / \mathrm{ml}$ & $\mathrm{IC} 50=3.48 \pm 0.22 \mu \mathrm{g} / \mathrm{ml}$ \\
\hline
\end{tabular}

Results are means \pm SD $(\mathrm{n}=3) P<0.05$

The cytotoxic activity of the plant extracts was evaluated using MTT assay. The EAF showed higher cytotoxic activity against the three cell lines, with $\mathrm{IC}_{50}=12.3 \pm 1.82 \mu \mathrm{g} / \mathrm{ml}, \mathrm{IC}_{50}=14.2 \pm 0.60 \mu \mathrm{g} / \mathrm{ml}$ and $\mathrm{IC}_{50}=$ $18.5 \pm 3.29 \mu \mathrm{g} / \mathrm{ml}$ respectively, while the AME showed higher cytotoxic activity on the MCF-7 and HepG2 cells, whereas it showed moderate activity against HeLa cell with $\mathrm{IC}_{50}=12.8 \pm 1.04 \mu \mathrm{g} / \mathrm{ml}, \mathrm{IC}_{50}=$ $10.7 \pm 0.37 \mu \mathrm{g} / \mathrm{ml}$ and $\mathrm{IC}_{50}=26.3 \pm 2.83 \mu \mathrm{g} / \mathrm{ml}$ respectively, as compared to Vinblastine Sulfate with $\mathrm{IC}_{50}=5.44 \pm 0.57 \mu \mathrm{g} / \mathrm{ml}, \mathrm{IC}_{50}=$ $3.48 \pm 0.22 \mu \mathrm{g} / \mathrm{ml}$ and $\mathrm{IC}_{50}=6.54 \pm 0.39 \mu \mathrm{g} / \mathrm{ml}$ respectively.

\section{Docking study}

Docking is the most widely used drug design tool in which the exact binding mode between the receptor and the ligand could be predicted But docking procedure should always be validated and compared to a
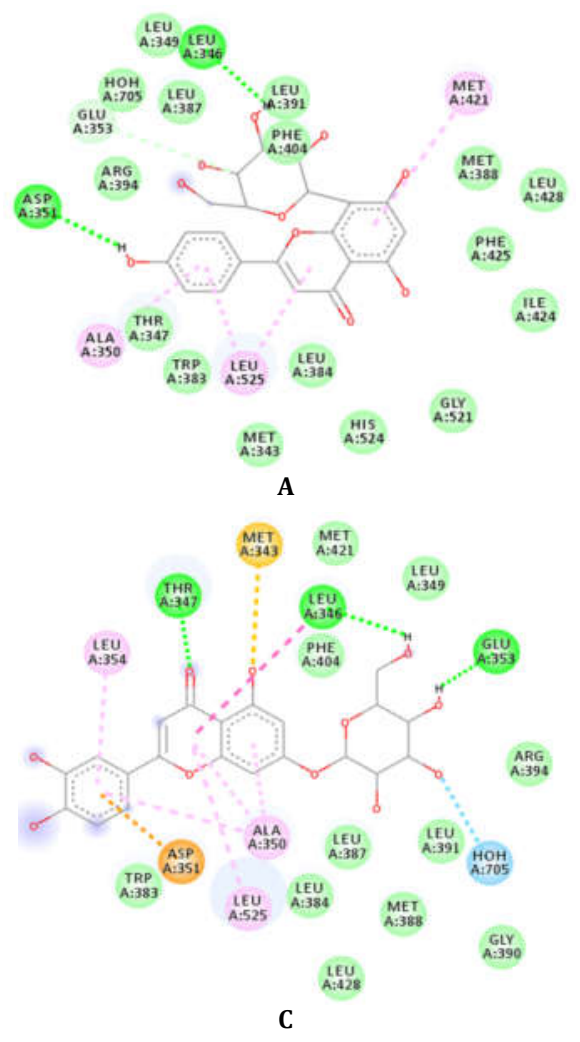

reference crystal structure. Thus the co-crystalized ligand in Estrogen receptor (PDB ID: 5t92) was docked to its corresponding active site. The calculated RMSD between the co-crystalized ligand and the docked pose was $1.55 \AA$ in the NW-docking (docking without water) and less than 0.2 $\AA$ in the $\mathrm{W}$-docking (docking with water), indicating a valid docking protocol. Because of the different results of the NW-docking and the Wdocking, the water molecules were kept in the docking procedure [28]. Finally, the pure isolated compounds were docked in the estrogen receptor. The docking result was analyzed using Discovery Studio 4.5.

The binding of the five compounds with the receptor was strong and involved many types of interactions. Table 8 summarizes the binding affinity scores of the three compounds and their most significant interactions with the receptor. The good binding mode of the three compounds is shown in (fig. 2).

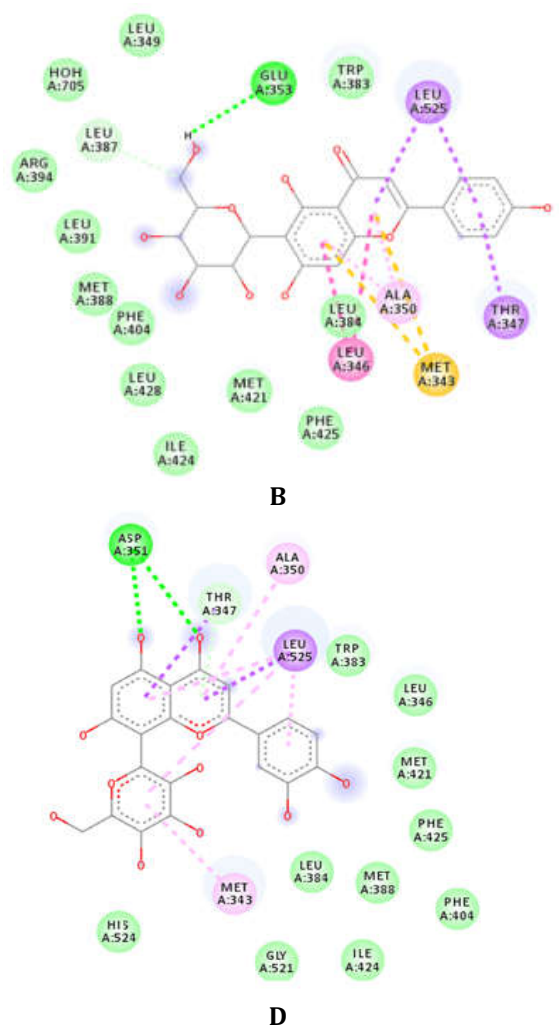



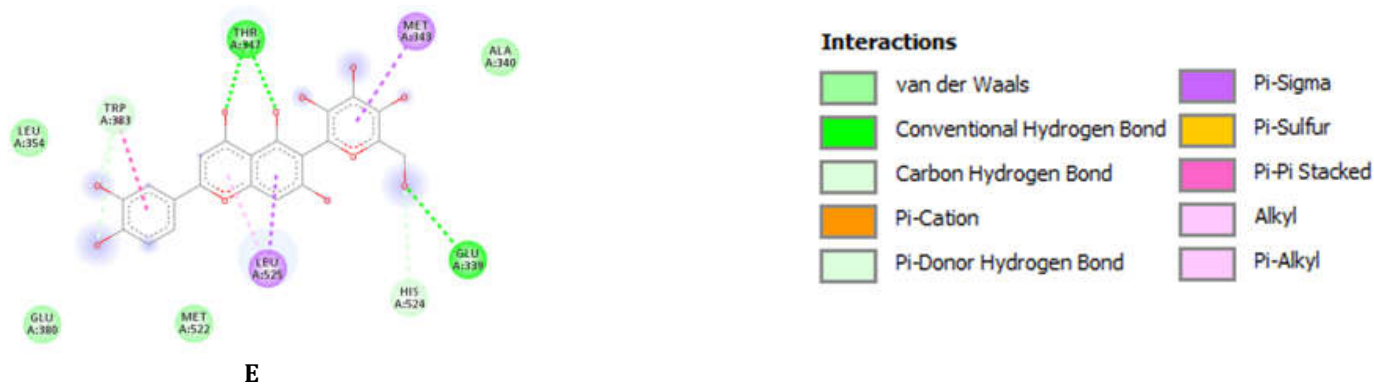

E

Fig. 2: The 2D interaction diagram of the three compounds with the estrogen receptor. (A) Vitexin, (B) Isovitexin, (C) Luteolin-7-0glucoside (D) Orientin and (E) isoorientin

Table 8: The binding affinity scores of isolated compounds and their most significant interactions with the receptor

\begin{tabular}{llll}
\hline Compound name & $\begin{array}{l}\text { Vina score } \\
\text { (Kcal/MOI) }\end{array}$ & $\begin{array}{l}\text { Residues involved in hydrogen bonds } \\
\text { interactions }\end{array}$ & Residues involved in hydrophobic interactions \\
\hline Vitexin & -6.8 & GLU353, LEU346 and ASP351 & MET421, ALA350and LEU525 \\
Isovitexin & -5.8 & GLU353 & MET343, LEU346, THR347, ALA350 and LEU525 \\
Luteolin-7- $O$-glucoside & -7.5 & GLU353, LEU346, THR347 and H2O705 & MET343, LEU346, ALA350, ASP351, LEU354 and LEU525 \\
Orientin & -4.6 & ASP351 and THR347 & MET343, THE347, ALA350, HIS524 and LEU525 \\
Isoorientin & -4.6 & THR347, TRP383, HIS524 and GLU339 & MET343, TRP 383 and LEU525 \\
\hline
\end{tabular}

Results of the molecular docking of vitexin, isovitexin, luteolin-7-0-glucoside, orientin and Isoorientin in estrogen receptor revealed a favorable bind mode with high docking score, which may confirm the higher cytotoxic activity of the EAF.

\section{CONCLUSION}

Chromatographic separation of the EAF of D. leptocheilos leaves led to isolation and identification of five phenolic compounds for the first time from this plant species, namely apigenin 8-C- $\beta$-Dglucopyranoside (Vitexin) (1), apigenin 6 -C- $\beta$-D-glucopyranoside (Isovitexin) (2), luteolin 7-O- $\beta$-D-glucopyranoside (3), luteolin 8-C- $\beta$ D-glucopyranoside (Orientin) (4), luteolin 6-C- $\beta$-D-glucopyranoside (Isoorientin) (5). The AME and EAF were evaluated for their antioxidant activity using DPPH assay; both showed similar and powerful antioxidant activity which attributed to the polyphenolic content. The antimicrobial activity of two extracts was found to be moderate against bacteria and very weak against fungi. Cytotoxic activity also has been evaluated for both extracts.

\section{ACKNOWLEDGMENT}

The authors are thankful to Ass. Prof. Dr. Radwan Elhaggar, Department of Pharmaceutical Chemistry, Faculty of Pharmacy, Helwan University, Cairo, Egypt for his valuable effort during the molecular docking study.

\section{FUNDING}

$\mathrm{Nil}$

\section{AUTHORS CONTRIBUTIONS}

Eman G. Haggag revised the manuscript; Haitham A. Ibrahim, Fatehia S. Elsharawy and Samah S. Shabana conducted the chromatographic separation, performed the structure elucidation of the pure isolated compounds and were responsible for drafting and writing the final version of the manuscript. Mahmmoud A. Elhassab performed the molecular docking study. All authors performed the antimicrobial, antioxidant and cytotoxicity assays and their data analysis in addition, they read and approved the final manuscript.

\section{CONFLICTS OF INTERESTS}

Authors declared no conflict of interest.

\section{REFERENCES}

1. Villamil PA, Burbano AC, Ospina LP, Palacios JA, Aguirre OE Determination of antimicrobial activity in leaves and flowers of Chromolaena scabra (L. F.) R. M. king and H. Rob. Asian J Pharm Clin Res 2020;13:53-6.
2. Pavithr S, Sekar T. Phytochemical profiling, free-radical scavenging and anti-inflammatory activities of meliosma simplicifolia (L.). Int J Pharm Pharm Sci 2020;12:62-8.

3. Dransfield J, Beentje $\mathrm{H}$. The palms of madagascar, royal botanic gardens, kew and the international palm society; 1995.

4. Imtilemla A, Bareh V, Barbhuiya SB, Sailo L. Preliminary phytochemical screening and in vitro antioxidant activity of the methanolic extract of Lindernia ruellioides (Colsm.) pennell. Asian J Pharm Clin Res 2020;13:141-6.

5. Lengauer T, Rarey M. Computational methods for biomolecular docking. Curr Opin Struct Biol 1996;6:402-6.

6. Meng EC, Shoichet BK, Kuntz ID. Automated docking with grid-based energy evaluation. J Comput Chem 1992;13:505-24.

7. Mabry TJ, Markham KR, Thomas MB. Ultraviolet spectra of isoflavones, flavanones and dihydroflavonols in the systematic identification of flavonoids. Springer Berlin Heidelberg; 1970. p. 165-226.

8. Yen GC, Duh PD. Scavenging effect of methanol extracts of peanut hulls on free radical and active oxygen species. J Agric Food Chem 1994;42:629-32.

9. Hindler JA, Howard BJ, Keiser JF. Antimicrobial agents and susceptibility testing. In: Howard BJ. (Editor). Clinical and Pathogenic Microbiology. Mosby-Year Book Inc. St. Louis, MO, USA; 1994.

10. Mosmann T. Rapid colorimetric assay for cellular growth and survival application to proliferation and cytotoxicity assays. J Immunol Methods 1983;65:55-63.

11. Gomha SM, Riyadh SM, Mahmmoud EA, Elaasser MM. Synthesis and anticancer activities of thiazoles, 1, 3-thiazines, and thiazolidine using chitosan-grafted-poly (vinyl pyridine) as basic catalyst. Heterocycles 2015;91:1227-43.

12. Trott 0 , Olson AJ. Auto dock vina: improving the speed and accuracy of docking with a new scoring function, efficient optimization and multithreading. J Comput Chem 2010;31:455-61.

13. Abagyan R, Totrov M, Kuznetsov D. ICM-a a new method for protein modeling and design: Applications to docking and structure prediction from the distorted native conformation. J Comput Chem 1994;15:488-506.

14. Baxter J. Local optima avoidance in depot location. J Oper Res Soc 1981;32:815-9.

15. Blum A, Blesa M, Sampels M. Hybrid metaheuristics: an emerging approach to optimization (Eds.). Berlin, Heidelberg: Springer-Verlag; 2008. p. 261-89. 
16. Nassar MI, Gaara AH, Marzouk MS, El-Din E, El-Khrisy AM Anew gentisic acid glycoside and C-glycosyl flavones from Erythrina indica with the antioxidant activity evaluation. Bull Fac Pharm Cairo Univ 2003;41:207-9.

17. El-Toumy SA, Omara EA, Nada SA, Bermejo J. Flavone Cglycosides from Montanoa bipinnatifida stems and evaluation of hepatoprotective activity of extract. JMPR 2011;5:1291-6.

18. Kubacey TM, Haggag EG, El-Toumy SA, Ahmed AA, El-Ashmawy IM Youns MM. Biological activity and flavonoids from Centaurea alexanderina leaf extract. J Pharm Res 2012;5:3352-61.

19. Li H, Zhou P, Yang Q, Shen Y, Deng J, Li L, et al. Comparative studies on anxiolytic activities and flavonoid compositions of Passiflora edulis 'edulis' and Passiflora edulis 'flavicarpa'. J Ethnopharmacol 2011;133:1085-90.

20. Choo CY, Sulong NY, Man F, Wong TW. Vitexin and isovitexin from the leaves of Ficus deltoidea with in vivo $\alpha$-glucosidase inhibition. J Ethnopharmacol 2012;142:776-81.

21. Mohamed TK, Kamal AM, Nassar MI, Ahmed MA, Haggag EG Ezzat HA. Phenolic contents of Gleditsia triacanthos leaves and evaluation of its analgesic anti-inflammatory, hepatoprotective and antimicrobial activities. Life Sci I 2013;10:3445-66.

22. Agrawal PK, Thakur RS, Bansal MC. In ${ }^{13} \mathrm{C}$ NMR of flavonoids agrawal (ed) Elsevier, New York; 1989;6:287-93.

23. Zhang $\mathrm{Y}$, Jiao J, Liu $\mathrm{C}, \mathrm{Wu} \mathrm{X}$, Zhang Y. Isolation and purification of four flavone C-glycosides from antioxidant of bamboo leaves by macroporous resin column chromatography and preparative high-performance liquid chromatography. Food Chem 2008;107:1326-36.

24. Sezik E, Aslan M, Yesilada E, Ito S. Hypoglycaemic activity of Gentiana olivieri and isolation of the active constituent through bioassay-directed fractionation techniques. Life Sci J 2005;76:1223-38.

25. Chiruvella KK, Mohammed A, Dampuri G, Ghanta RG, Raghavan SC. Phytochemical and antimicrobial studies of methyl angolensate and luteolin-7-O-glucoside isolated from callus cultures of Soymida febrifuga. Int J Biomed Sci 2007;3:269.

26. Chandrika M, Chellaram M. Efficacy of antioxidation and antiinflammation of the leaf extracts of borreria hispida. Int J Pharm Pharm Sci 2016;8:369-72.

27. Ibrahim RR, Ibrahim HA, Shabana SS, El-Hosari DG, Ali SA Mahgoub S, et al. New phenolic compounds from calothamnus quadrifidus R. Br. aerial parts and their antioxidant activity. Nat Prod Res 2020;8:1-9.

28. Wei Y, Li J, Qing J, Huang M, Wu M, Gao F, et al. Discovery of novel hepatitis $\mathrm{c}$ virus NS5B polymerase inhibitors by combining random forest, multiple e-pharmacophore modeling and docking. PLoS ONE 2016;11(Suppl 2):e0148181. 